\title{
Pathophysiological Justification for Allergen Immunotherapy in Food Allergy
}

\author{
Marta Chełmińska1,2, Katarzyna Puźniakowska² \\ ${ }^{1}$ Klinika Alergologii Katedry Pneumonologiii Alergologii, Gdański Uniwersytet Medyczny, Poland \\ ${ }^{2}$ Klinika Alegologiii Pneumonologii, Uniwersyteckie Centrum Kliniczne, Gdańsk, Poland \\ Email: kpuzniakowska@wp.pl
}

Received 16 March 2016; accepted 25 April 2016; published 28 April 2016

Copyright (C) 2016 by authors and Scientific Research Publishing Inc.

This work is licensed under the Creative Commons Attribution International License (CC BY).

http://creativecommons.org/licenses/by/4.0/

c) (i) Open Access

\begin{abstract}
Apart from avoiding exposure, allergen immunotherapy (AI) is the only causal method of treating allergic diseases. The results of numerous studies have been published concerning the safety and effectiveness of the AI in treating allergic rhinitis, asthma or allergy to the venom of Hymenoptera insects. It has also been proven that administration of increasing preparation doses of allergen extractions alleviates the symptoms in patients after the exposure to some sensitizing allergens. The effect of the AI remains visible many years after completion of the therapy. Studies have been done in an attempt to employ specific immunotherapy in patients with food allergy symptoms. They have been mostly concerned with populations of patients suffering from allergy to the protein found in cow's milk and hen eggs. It appears that a need arises to create a new therapeutic method for successful treatment of food allergies and specific allergen immunotherapy seems to be a promising step. Although still in its experimental phase, in many well documented cases the method allows for building patient's tolerance towards small doses of sensitizing allergen and seems conducive to protecting the patient from anaphylactic reactions after incidental allergen consumption.
\end{abstract}

\section{Keywords}

Food Allergy, Immunotherapy, Allergy, Pathophysiology

\section{Introduction}

Apart from avoiding exposure, allergen immunotherapy (AI) is the only causal method of treating allergic diseases. The first successful allergen immunotherapy (AI) described for food allergy was published in 1912 by Oscar Schloss [1]. The results of numerous studies have been published concerning the safety and effectiveness 
of the AI in treating allergic rhinitis, asthma or allergy to the venom of Hymenoptera insects. It has also been proven that administration of increasing preparation doses of allergen extractions alleviates the symptoms in patients after the exposure to some sensitizing allergens. Apart from improving the patient's clinical condition, the aim of the AI is to obtain a proper immunological answer to prevent the development of possible allergies in the future. The effect of the AI remains visible many years after completion of the therapy [2]-[4].

\section{Immunological Changes Due to Immunotherapy}

The effectiveness of immunotherapy has been proven to depend on a change of lymphocyte profile Th2 into allergen-protective Th1. The change causes inhibition of the production of cytokines by Th2, such as interleukins (IL) $-4,-5$, and -13 , and also an increase in the production of cytokines like interferon- $\gamma$ (INF- $\gamma$ ) or IL-12. In the process of AI activation of regulatory T lymphocytes (Treg), synthesis increases of both the IL-10 and the transforming growth factor- $\beta$ (TGF- $\beta$ ). Initially, an increase and then a decrease in immunoglobulin $\mathrm{E}$ (IgE) are observed along with some increase in IgG4 (the change of class IgG1 into IgG4) and/or IgA. Consequently, inhibition is seen of such effector cells as eosinophils, basofils and mast cells. Irrespective of the route of administering the allergen (subcutaneous or sublingual), the immunological answer is similar and strictly depends both on dose and length of the therapy [2] [5]-[7].

Analysis of the AI mechanism has been carried out along with some research on the role of the receptors for the fragment of Fc IgE of high affinity (Fc $\varepsilon$ receptor type I, Fc $\varepsilon$ RI) and of histamine receptors (HR). The studies of Nowak et al. on the early inhibition of basophile activation during the AI by HR2 done on a group of patients undergoing immunotherapy has proven that it may have a significant importance in building a very early allergen tolerance and a distant desensitizing effect [8].

\section{Pathomechanisms of Food Allergy}

According to Gell and Coombs' classification, pathomechanism of food allergy (FA) involves all types of immunological responses [9].

Reactions Type 1 that are immediate and IgE dependent constitute about $50 \%$ of all FA cases. The occurrence of such reactions is connected with the activation of mast cells of the alimentary system (gastrointestinal associated lymphoid tissue, GALT), of the skin (skin associated lymphoid tissue, SALT), and of the bronchi (bronchial associated lymphoid tissue, BALT) [10]. As a result, from mast cells and basophiles mediators (e.g. histamine, serotonin) are released along with cytokines (TNF-a, IL-4, IL-5, IL-6, IL-8). Degranulation of mast cells and basofiles happening in the alimentary tract is analogical to that seen in the respiratory tract in that it binds specific IgE antibodies to the receptors located on them these receptors are of high affinity (Fc $\varepsilon$ RI ) and to the receptors of low affinity(FceRII ) on macrophages and neutrophils [11].

IgE-independent reactions, cytotoxic type II, type III-with the participation of immunological complexes, and type IV - cellular ones, are found in $6 \%, 10 \%$, and $18 \%$ of cases, respectively. Due to hypersensitivity, symptoms in $28 \%$ of patients are caused by more than one type of reaction [12].

Cross reactions may also be responsible for the manifestation of symptoms and our insight into them allows for a more penetrating analysis of the development mechanism of symptoms seen in patients upon food products consumption. Differentiation of reaction types resulting from true allergy is necessary due to variations in treatment (symptomatic treatment or specific immunotherapy).

Cross-reactivity defined as an allergy to common epitopes binding specific IgE of various allergens is seen as one of the most important issues in modern allergy. Reactions are triggered when antibodies of class E produced primarily towards one allergen recognize a different source protein. This may possibly lead to a situation in which a patient experiences at the same time hypersensitivity to inhalant, food and contact allergens. Of basic pathogenetic importance is the similarity between structures of primary and tertiary allergen proteins and the aminoacid sequence whose compatibility of over 70\% constitutes a real risk of cross-reactivity [13]-[15]. Commonly occurring panallergens (profilins, chitinases and lipid transfer proteins) have the leading role in triggering cross-reactions [15].

Profilins constitute a family of proteins of specific weight from 15 to $18 \mathrm{kDa}$. Found in grass, tree and weed pollens and many fruits and vegetables, they regulate the actin binding in eukaryotic cells and are responsible for passing the signal along the phosphatidylinositol path [16]. Allergy to profilin is diagnosed in $20 \%-43 \%$ of patients with pollen and food allergy [17] [18]. 
Chitinases are recognized as two groups of proteins: chitinases of class I and class II. Hevein, a protein of specific weight of $30-45 \mathrm{kDa}$, represents class I. It constitutes the main allergen found in fruit that is connected with the so called latex-fruit syndrome ( $\mathrm{Hev} \mathrm{b} 11$ and $\mathrm{Hev} \mathrm{b} \mathrm{6.02).} \mathrm{Class} \mathrm{II} \mathrm{chitinases} \mathrm{show} \mathrm{a} \mathrm{60 \% -homology} \mathrm{to}$ class I. The two classes are found in avocados, bananas and chestnuts (Castanea sativa) [16]. Endochitynase 4A is the main allergen in grapes that is responsible for severe anaphylactic reactions. It has been also found to keep its properties in wine. Also grapes have LTP which is responsible for the cross-reaction with peaches [19].

Lipid transfer proteins (LTP) are proteins of specific weight from 10 to $13 \mathrm{kDa}$ that are widely spread in nature and are highly stable and resistant to being digested with pepsin. They take part in transport of lipids within the cellular membrane and contribute to plant protective mechanism against various environmental pathogens. They are also present in fruit, vegetables and legume as well as grass, tree and weed pollens [20]-[23]. Hypersensitivity to this group of allergens is the cause of severe anaphylactic reactions [16]. The symptoms are usually stronger than those seen in oral allergy syndrome (OAS), and may be of systemic character [21] [24]. These proteins are resistant to temperature and allergic reactions they trigger may develop after consuming thermally processed food. Cross-reactions between LTP of various allergens are known as LTP syndrome.

Cross-reactive carbohydrate determinants (CCDs) are common for plant, fruit and vegetable pollens [25]-[27]. They are N- and O-glycans constituting glycoproteins of plants and organisms of invertebrates. The clinical symptoms associated with CCDs are infrequent, yet in some patient groups they manifest dramatically [28]. Such symptoms are noticed in people allergic to wasp, bee venom and latex [16] [29]-[31], and particularly in individuals consuming too much alcohol [32]-[34]. Yet another important allergen belonging to the group specified above is bromelain found in pineapples (Ana c 2) [20].

Other plant- origin allergens that cause cross-reactions have not been found to create this dependence on latex allergen. Such allergens include polycalcines-allergen proteins of pollens which have the ability to bind calcium [16] [35], and homological proteins with Bet v 1 (pathogenesis-related protein PR-10). Studies have also been done on cyclophylins, taumatin proteins and storage proteins [16] [36].

Similarly, among the allergens of non-plant origin, there are allergens that have the ability to trigger crossreactions whose the reactivity, however, towards latex allergy has not been proven. Tropomyosin, one of these allergens, originates from muscle fibres of shrimps, crabs and oysters and is a marker of cross-reactions between house dust mites, shellfish and cockroaches [37]. Parvalbumin, another allergen of the kind, is found in various fish species and causes cross-reactions between different fish species and amphibians [38]-[41]. The allergen that triggers a reaction to fish is the allergen of fish parasite (Anisakis simplex) [14] [42]. Another protein of animal origin is serum albumin. Present in blood, milk, eggs and meat (chicken, beef), it is responsible for cross-reactions between the albumin of various animal species (pork-cat, beef-dog syndrome [43]-[45]. Drouet [46] presented a case of a severe anaphylactic reaction that ended in death of a patient previously diagnosed with pork-cat syndrome, who ate boar meat. What builds a link between plant and animal worlds is lipocaine isolated both from plant allergens (apples, cherries, strawberries, pepper) and animal allergens (dog, cat, mouse, cow, horse, cockroach). Lipocaine has been found to trigger limited cross-reactions between species [14].

\section{Conclusions}

Studies have been done in an attempt to employ specific immunotherapy in patients with food allergy symptoms. They have been mostly concerned with populations of patients suffering from allergy to the protein found in cow's milk [47] [48] and hen eggs [49]-[51]. All the authors have stressed the high efficacy and safety of the therapy measured by determining specific IgE, IgG4 and IgG1. Changes in humoral and cellular immunity associated to AI determine occurrence of desensitisation and long-term tolerance [52]. Some investigations have been published in which patients allergic to peanuts, hazelnuts and fruit [53]-[56] have undergone immunotherapy. Some studies have employ recombinant allergens and Fernandez-Rivas, for example, presented the results of a six-month therapy with peach allergen (e.g. Pru p 3) which belongs to LTP [57]. The results of phase 2 study of recombinant hypoallergenic vaccine (Cyp c1) for fish allergy are under evaluation [58]. A case of successful sublingual immunotherapy in patient with severe anaphylactic reactions due to kiwi fruit allergy was described [59] [60]. Possibility of long term tolerance was established by change in IgE and IgG status [60].

Genetically modified food was first used a few years ago for AI [61] [62] and this method requires further thorough and specific studies.

It appears that a need arises to create a new therapeutic method for successful treatment of food allergies and 
specific allergen immunotherapy seems to be a promising step. Although still in its experimental phase, in many well documented cases the method allows for building patient's tolerance towards small doses of sensitizing allergen and seems conducive to protecting the patient from anaphylactic reactions after incidental allergen consumption. Creating recombinant allergens and standardized concentrations of allergens in vaccines allows credible comparison of the results of immunotherapy [57]-[59]. Achieving repeatable long-term tolerance by AI protocols is a next step in determining the future management of food allergy [2] [5] [52] [63].

\section{References}

[1] Schloss, O.M. (1912) A Case of Allergy to Common Foods. American Journal of Diseases of Children, 3, $342-362$.

[2] Akdis, C.A. and Akdis, M.M. (2011) Mechanisms of Allergen-Specific Immunotherapy. Journal of Allergy and Clinical Immunology, 127, 18-27. http://dx.doi.org/10.1016/j.jaci.2010.11.030

[3] Fujita, H., Soyka, M.B., Akdis, M., et al. (2012) Mechanisms of Allergen-Specific Immunotherapy. Clinical and Translational Allergy, 2, 2. http://dx.doi.org/10.1186/2045-7022-2-2

[4] Maggi, E., Vultaggio, A. and Matucci, A. (2012) T-Cell Responses during Allergen-Specific Immunotherapy. Current Opinion in Allergy \& Clinical Immunology, 12, 1-6. http://dx.doi.org/10.1097/ACI.0b013e32834ecc9a

[5] Akdis, M., Verhagen, J., Taylor, A., et al. (2004) Immune Responses in Healthy and Allergic Individuals Are Characterized by a Fine Balance between Allergen-Specific T Regulatory 1 and T Helper 2 Cells. The Journal of Experimental Medicine, 199, 1567-1575. http://dx.doi.org/10.1084/jem.20032058

[6] Jutel, M., Akdis, M., Budak, F., et al. (2003) Il-10 and TGF- $\beta$ Cooperate in the Regulatory T Cell Response to Mucosal Allergens in Normal Immunity and Specific Immunotherapy. European Journal of Immunology, 33, 1205-1214. http://dx.doi.org/10.1002/eji.200322919

[7] Robinson, D.S., Larche, M. and Durham, S.R. (2004) Tregs and Allergic Disease. Journal of Clinical Investigation, 114, 1389-1397. http://dx.doi.org/10.1172/JCI200423595

[8] Novak, N., Mate, N., Bussmann, C., Maintz, L., Bieber, T., Akdis, M., Zumkehr, J., Jutel, M. and Akdis, C. (2012) Early Suppression of Basophil Activation during Allergen-Specific Immunotherapy by Histamine Receptor 2. Journal of Allergy and Clinical Immunology, 130, 1153-1158. http://dx.doi.org/10.1016/j.jaci.2012.04.039

[9] Zukiewicz-Sobczak, W.A., Wróblewska, P., Adamczuk, P. and Kopczyński, P. (2013) Causes, Symptoms and Prevention of Food Allergy. Postepy Dermatologii I Alergologii, 30, 113-116. http://dx.doi.org/10.5114/pdia.2013.34162

[10] Sabra, A., Bellanti, J.A., Rais, J.M., et al. (2003) IgE and Non-IgE Food Allergy. Annals of Allergy, Asthma \& Immunology, 90, 71-76. http://dx.doi.org/10.1016/S1081-1206(10)61664-X

[11] Shah, U. and Walker, W.A. (2002) Pathophysiology of Intestinal Food Allergy. Advances in Pediatrics, 49, $299-316$.

[12] Chandra, R.K. and Gill, B. (1993) Food Allergy and Atopic Disease: Pathogenesis, Diagnostic, Prediction. Annals of Allergy, 71, 495-502.

[13] Aalberse, R.C., Akkerdaas, J. and Van Ree, R. (2001) Cross-Reactivity of IgE Antibodies to Allergens. Allergy, 56, 478-490. http://dx.doi.org/10.1034/j.1398-9995.2001.056006478.x

[14] Aalberse, R.C. (2000) Structural Biology of Allergens. The Journal of Allergy and Clinical Immunology, 106, $228-238$. http://dx.doi.org/10.1067/mai.2000.108434

[15] Weber, R.W. (2003) Pattern of Pollen Cross-Allergenicity. The Journal of Allergy and Clinical Immunology, 112, 229239. http://dx.doi.org/10.1067/mai.2003.1683

[16] Ferreira, F., Hawranek, T., Gruber, P., Wopfner, N. and Mari, A. (2004) Allergic Cross-Reactivity: From Gene to the Clinic. Allergy, 59, 243-267. http://dx.doi.org/10.1046/j.1398-9995.2003.00407.x

[17] Asero, R., Monsalve, R. and Barber, D. (2008) Profilin Sensitization Detected in the Office by Skin Prick Test: A Study of Prevalence and Clinical Relevance of Profiling as a Plant Food Allergen. Clinical \& Experimental Allergy, 38, 1033-1037. http://dx.doi.org/10.1111/j.1365-2222.2008.02980.x

[18] Fedorov, A.A., Ball, T., Mahoney, N.M., Valenta, R. and Almo, S.C. (1997) The Molecular Basis for Alergen CrossReactivity: Crystal Structure and IgE-Epitope Mapping of Birch Pollen Profilin. Structure, 5, 33-45. http://dx.doi.org/10.1016/S0969-2126(97)00164-0

[19] Pastorello, E.A., Farioli, L., Pravettoni, V., Ortolani, C., Fortunato, D., Giuffrida, M.G., et al. (2003) Identification of Grape and Wine Allergens as an Endochitinase 4, a Lipid-Transfer Protein, and a Thaumatin. The Journal of Allergy and Clinical Immunology, 111, 350-359. http://dx.doi.org/10.1067/mai.2003.35

[20] Allergen Nomenclature. IUIS Allergen Nomenclature Sub-Committee. www.allergen.org

[21] Breiteneder, H. and Mills, C. (2005) Nonspecific Lipid-Transfer Proteins in Plant Foods and Pollens: An Important Allergen Class. Current Opinion in Allergy and Clinical Immunology, 5, 275-279.

http://dx.doi.org/10.1097/01.all.0000168794.35571.a5 
[22] Romano, A., Fernandez-Rivas, M., Caringi, M., Amato, S., Mistrello, G. and Asero, R. (2009) Allergy to Peanut Lipid Transfer Protein (LTP): Frequency and Cross-Reactivity between Peanut and Peach LTP. European Annals of Allergy and Clinical Immunology, 41, 106-111.

[23] San Miguel-Moncín, M., Krail, M., Scheurer, S., Alonso, R., Conti, A., et al. (2003) Lettuce Anaphylaxis: Identification of a Lipid Transfer Protein as a Major Allergen. Allergy, 58, 511-517. http://dx.doi.org/10.1034/j.1398-9995.2003.00097.x

[24] Lauer, I., Dueringer, N., Pokoj, S., Rehm, S., Zoccatelli, G., Reese, G., et al. (2009) The Non-Specific Lipid Transfer Protein, Ara h 9, is an Important Allergen in Peanut. Clinical \& Experimental Allergy, 39, 1427-1437. http://dx.doi.org/10.1111/j.1365-2222.2009.03312.x

[25] Foetisch, K., Westphal, S., Lauer, I., Retzek, M., Altmann, F., Kolarich, D., et al. (2003) Biological Activity of IgE Specific for Cross-Reactive Carbohydrate Determinants. The Journal of Allergy and Clinical Immunology, 111, 889896. http://dx.doi.org/10.1067/mai.2003.173

[26] Van der Veen, M.J., van Ree, R., Aalberse, R.C., Akkerdaas, J., Koppelman, S.J., Jansen, H.M. and van der Zee, J.S. (1997) Poor Biologic Activity of Cross-Reactive IgE Directed to Carbohydrate Determinants of Glycoproteins. The Journal of Allergy and Clinical Immunology, 100, 327-334. http://dx.doi.org/10.1016/S0091-6749(97)70245-8

[27] Vieths, S., Scheurer, S. and Ballmer-Weber, B. (2002) Current Understanding of Cross-Reactivity of Food Allergens and Pollen. Annals of the New York Academy of Sciences, 964, 47-68. http://dx.doi.org/10.1111/j.1749-6632.2002.tb04132.x

[28] Mari, A. (2002) IgE to Cross-Reactive Carbohydrate Determinants: Analysis of the Distribution and Appraisal of the in Vivo and in Vitro Reactivity. International Archives of Allergy and Immunology, 129, 286-295. http://dx.doi.org/10.1159/000067591

[29] Hemmer, W., Focke, M., Kolarich, D., Dalik, I., Götz, M. and Jarisch, R. (2004) Identification by Immunoblot of Venom Glycoproteins Displaying Immunoglobulin E-Binding N-Glycans as Cross-Reactive Allergenes in Honeybee and Yellow Jacket Venom. Clinical \& Experimental Allergy, 34, 460-469. http://dx.doi.org/10.1111/j.1365-2222.2004.01897.x

[30] Jappe, U., Raulf-Heimsoth, M., Hoffmann, M., Burow, G., Hübsch-Müller, C. and Enk, A. (2006) In Vitro Hymenoptera Venom Allergy Diagnosis: Improved by Screening for Cross-Reactive Carbohydrate Determinants and Reciprocal Inhibition. Allergy, 61, 1220-1229. http://dx.doi.org/10.1111/j.1398-9995.2006.01232.x

[31] Mahler, V., Gutgesell, C., Valenta, R. and Fuchs, T. (2006) Natural Rubber Latex and Hymenoptera Venoms Share ImmunoglobulinE-Epitopes Accounting for Cross-Reactive Carbohydrate Determinations. Clinical \& Experimental Allergy, 36, 1446-1456. http://dx.doi.org/10.1111/j.1365-2222.2006.02587.x

[32] Coutinho, V., Vidal, C., Garrido, M., Gude, F., Lojo, S., Linneberg, A. and Gonzalez-Quintela, A. (2008) Interference of Cross-Reactive Carbohydrates in the Determination of Specific IgE in Alcohol Drinkers and Strategies to Minimize It: The Example of Latex. Annals of Allergy, Asthma \& Immunology, 101, 394-401. http://dx.doi.org/10.1016/S1081-1206(10)60316-X

[33] Gonzalez-Quintela, A., Garrido, M., Gude, F., Campos, J., Linneberg, A., Lojo, S. and Vidal, C. (2007) Sensitization to Cross-Reactive Carbohydrate Determinants in Relation to Alcohol Consumption. Clinical \& Experimental Allergy, 38, 152-160. http://dx.doi.org/10.1111/j.1365-2222.2007.02863.x

[34] Vidal, C., Vizcaino, L., Diaz-Peromingo, J.A., Garrido, M., Gomez-Rial, J., Linneberg, A. and Gonzalez-Quintela, A. (2009) Immunoglobulin-E Reactivity to a Glycosylated Food Allergen (Peanuts) Due to Interference with Cross-Reactive Carbohydrate Determinants in Heavy Drinkers. Alcoholism: Clinical and Experimental Research, 33, 1322-1328. http://dx.doi.org/10.1111/j.1530-0277.2009.00961.x

[35] Mari, A. (2001) Multiple Pollen Sensitization: A Molecular Approach to the Diagnosis. International Archives of Allergy and Immunology, 125, 57-65. http://dx.doi.org/10.1159/000053797

[36] Dooper, M.M., Plassen, C., Holden, L., Lindvik, H. and Faeste, C.K. (2009) Immunoglobulin E Cross-Reactivity between Lupine Conglutins and Peanut Allergens in Serum of Lupine-Allergic Individuals. Journal of Investigational Allergology and Clinical Immunology, 19, 283-291.

[37] Arlian, L.G., Morgan, M.S., Vyszenski-Moher, D.L. and Sharra, D. (2009) Cross-Reactivity between Storage and Dust Mites and between Mites and Shrimp. Experimental and Applied Acarology, 47, 159-172. http://dx.doi.org/10.1007/s10493-008-9199-x

[38] Bugajska-Schretter, A., Eltman, L., Fuchs, T., Kapiotis, S., Rumpold, H., Valenta, F. and Spitzauer, S. (1998) Parvalbumin, a Cross-Reactive Fish Allergen, Contains IgE-Binding Epitopes Sensitive to Periodate Treatment and $\mathrm{Ca}^{2+}$ Depletion. The Journal of Allergy and Clinical Immunology, 101, 67-74.

http://dx.doi.org/10.1016/S0091-6749(98)70195-2 
[39] Griesmeier, U., Vázquez-Cortés, S., Bublin, M., Radauer, C., Ma, Y., Briza, P., et al. (2010) Expression Levels of Parvalbumins Determine Allergenicity of Fish Species. Allergy, 65, 191-198. http://dx.doi.org/10.1111/j.1398-9995.2009.02162.x

[40] Ma, Y., Griesmeier, U., Susani, M., Radauer, C., Briza, P., Erler, A., et al. (2008) Comparison of Natural and Recombinant Forms of the Major Fish Allergen Parvalbumin from Cod and Carp. Molecular Nutrition \& Food Research, 52, 196-207. http://dx.doi.org/10.1002/mnfr.200700284

[41] Swoboda, I., Bugajska-Schretter, A., Verdino, P., Keller, W., Sperr, W.R., Valent, P., et al. (2002) Recombinant Carp Parvalbumin, the Major Cross-Reactive Fish Allergen: A Tool for Diagnosis and Therapy of Fish Allergy. The Journal of Immunology, 168, 4576-4584. http://dx.doi.org/10.4049/jimmunol.168.9.4576

[42] Antón, J., Escudero, R. and Fernández-Benítez, M. (2008) Anaphylaxis Induced by Anisakis. Allergologia et Immunopathologia, 36, 53-55. http://dx.doi.org/10.1157/13115670

[43] Drouet, M., Boutet, S., Lauret, M.G., Chène, J., Bonneau, J.C., Le Sellin, J., et al. (1994) The Pork-Cat Syndrome or Crossed Allergy between Pork Meat and Cat Epithelia (1). Allergie et Immunologie, 26, 166-168, 171-172.

[44] Sabbah, A., Lauret, M.G., Chène, J., Boutet, S. and Drouet, M. (1994) The Pork-Cat Syndrome or Crossed Allergy between Pork Meat and Cat Epithelia (2). Allergie et Immunologie, 26, 173-174, 177-180.

[45] San-Juan, S., Lezaun, A., Caballero, M.L. and Moneo, I. (2005) Occupational Allergy to Raw Beef Due to Cross-Reactivity with Dog Epithelium. Allergy, 60, 839-840. http://dx.doi.org/10.1111/j.1398-9995.2005.00582.x

[46] Drouet, M., Sabbah, A., Le Sellin, J., Bonneau, J.C., Gay, G. and Dubois-Gosnet, C. (2001) Fatal Anaphylaxis after Eating Wild Boar Meat in a Patient with Pork-Cat Syndrome. Allergie et Immunologie, 33, 163-165.

[47] Narisety, S.D., Skripak, J.M., Steele, P., Hamilton, R.G., Matsui, E.C., Burks, A.W. and Wood, R.A. (2009) OpenLabel Maintenance after Milk Oral Immunotherapy for IgE-Mediated Cow's Milk Allergy. The Journal of Allergy and Clinical Immunology, 124, 610-612. http://dx.doi.org/10.1016/j.jaci.2009.06.025

[48] Ruiter, B., Knol, E.F., van Neerven, R.J.J., Garssen, J., Bruijnzeel-Koomen, C.A.F.M., Knulst, A.C. and Van Hoffen, E. (2007) Maintenance of Tolerance to Cow's Milk in Atopic Individuals Is Characterized by High Levels of Specific Immunoglobulin G4. Clinical \& Experimental Allergy, 37, 1103-1110. http://dx.doi.org/10.1111/j.1365-2222.2007.02749.x

[49] Buchanan, A.D., Green, T.D., Jones, S.M., Scurlock, A.M., Christie, L., Althage, K.A., et al. (2007) Egg Oral Immunotherapy in Nonanaphylactic Children with Egg Allergy. The Journal of Allergy and Clinical Immunology, 119, 199-205. http://dx.doi.org/10.1016/j.jaci.2006.09.016

[50] Rodriguez, G.R., Urra, J.M., Feo-Brito, F., Galindo, P.A., Borja, J., Gómez, E., et al. (2011) Oral Rush Desensitization to Egg: Efficacy and Safety. Clinical \& Experimental Allergy, 41, 1289-1296. http://dx.doi.org/10.1111/j.1365-2222.2011.03722.x

[51] Vickery, B.P., Pons, L., Kulis, M., Steele, P., Jones, S.M. and Burks, A.W. (2010) Individualized IgE-Based Dosing of Egg Oral Immunotherapy and the Development of Tolerance. Annals of Allergy, Asthma \& Immunology, 105, 444-450. http://dx.doi.org/10.1016/j.anai.2010.09.030

[52] Carmen, C.M. and Urra, J.M. (2015) Food Allergy and the Oral Immunotherapy Approach. Archivum Immunologiae et Therapiae Experimentalis, 63, 31-39. http://dx.doi.org/10.1007/s00005-014-0304-z

[53] Enrique, E., Pineda, F., Malek, T., Bartra, J., Basagaña, M., Tella, R., et al. (2005) Sublingual Immunotherapy for Hazelnut Food Allergy: A Randomized, Double-Blind, Placebo-Controlled Study with a Standardized Hazelnut Extract. The Journal of Allergy and Clinical Immunology, 116, 1073-1079. http://dx.doi.org/10.1016/j.jaci.2005.08.027

[54] Jones, S.M., Pons, L., Roberts, J.L., Scurlock, A.M., Perry, T.T., Kulis, M., et al.(2009) Clinical Efficacy and Immune Regulation with Peanut Oral Immunotherapy. The Journal of Allergy and Clinical Immunology, 124, 292-300. http://dx.doi.org/10.1016/j.jaci.2009.05.022

[55] Nelson, H.S., Lahr, J., Rule, R., Bock, A. and Leung, D. (1997) Treatment of Anaphylactic Sensitivity to Peanuts by Immunotherapy with Injections of Aqueous Peanut Extract. The Journal of Allergy and Clinical Immunology, 99, 744751. http://dx.doi.org/10.1016/S0091-6749(97)80006-1

[56] Varshney, P., Jones, S.M., Scurlock, A.M., Perry, T.T., Kemper, A., Steele, P., et al. (2011) A Randomized Controlled Study of Peanut Oral Immunotherapy: Clinical Desensitization and Modulation of the Allergic Response. The Journal of Allergy and Clinical Immunology, 127, 654-60. http://dx.doi.org/10.1016/j.jaci.2010.12.1111

[57] Fernández-Rivas, M., Garrido Fernández, S., Nadal, J.A., Alonso Díaz de Durana, M.D., García, B.E., GonzálezMancebo, E., et al. (2009) Randomized Double-Blind, Placebo-Controlled trial of Sublingual Immunotherapy with a Pru p 3 Quantified Peach Extract. Allergy, 64, 876-883. http://dx.doi.org/10.1111/j.1398-9995.2008.01921.x

[58] ClinicalTrials.gov Identifier: NCT02017626. https://clinicaltrials.gov/

[59] Mempel, M., Rakoski, J., Ring, J. and Ollert, M. (2003) Severe Anaphylaxis to Kiwi Fruit: Immunologic Changes Related to Successful Sublingual Allergen Immunotherapy. The Journal of Allergy and Clinical Immunology, 111, 14061409. http://dx.doi.org/10.1067/mai.2003.1497 
[60] Kerzl, R., Simonowa, A., Ring, J., Ollert, M. and Mempel, M. (2007) Life-Threatening Anaphylaxis to Kiwi Fruit: Protective Sublingual Allergen Immunotherapy Effect Persists even after Discontinuation. The Journal of Allergy and Clinical Immunology, 119, 507-508. http://dx.doi.org/10.1016/j.jaci.2006.09.041

[61] Ma, S. and Jevanikar, A.M. (2005) Transgenic Rice for Allergy Immunotherapy. Proceedings of the National Academy of Sciences of the United States of America, 102, 17255-17256. http://dx.doi.org/10.1073/pnas.0509018102

[62] Saeki, M., Nishimura, T., Kaminuma, O., Suzuki, K., Takai, T., Mori, A., et al. (2012) Inhibition of Allergen-Induced Airway Inflammation by Low-Dose Oral Immunotherapy with Transgenic Rice Seeds Independently of Immunoglobulin E Synthesis. International Archives of Allergy and Immunology, 158, 66-69. http://dx.doi.org/10.1159/000337771

[63] Vickery, B.P., Chin, S. and Burks, W. (2011) Pathophysiology of Food Allergy. Pediatric Clinics of North America, 58, 363-376. http://dx.doi.org/10.1016/j.pcl.2011.02.012 